\title{
Sistem Informasi Penerimaan Peserta Didik Baru (PPDB) Berbasis WEB Di SMP Negri 1 Wanasari Brebes
}

\author{
Nur Ariesanto Ramdhan*1, Dimas Wahyudi ${ }^{2}$ \\ 1,2 teknik Informatika, Universitas Muhadi Setiabudi, Brebes, Indonesia \\ e-mail: ${ }^{1}$ nur.ariesanto.ramdhan@umus.ac.id, ${ }^{2}$ dimas@gmail.com
}

\begin{abstract}
Abstrak
Penerimaan siswa baru adalah salah satu proses di lembaga pendidikan seperti sekolah yang digunakan untuk memilih calon siswa sesuai dengan kriteria sekolah yang bersangkutan. Penelitian ini dilakukan di SMP Negeri 1 Wanasari Brebes yang masih melatih penerimaan siswa baru secara manual. Dalam penelitian, peneliti memutuskan untuk membuat Sistem Informasi penerimaan Siswa Berbasis Web di SMP Negeri 1 Wanasari Brebes. Sistem Informasi Penerimaan Siswa Berbasis Web akan menyediakan akses internet bagi orang-orang mengenai SMP Negeri 1 Wanasari Brebes. Tujuannya untuk membantu SMP Negeri 1 Wanasari Brebes membuat sistem penerapan dan manajemen data siswa yang efisien, terutama untuk siswa baru. Metode yang digunakan dalam penelitian ini adalah pengumpulan data, pengembangan sistem, analisis kebutuhan sistem, desain sistem, desain basis data, dan desain antarmuka. Kesimpulan penelitian ini adalah Sistem Informasi Penerimaan Siswa Berbasis Web di SMP Negeri 1 Wanasari Brebes akan dibangun dengan PHP dan MySQL, sehingga pengolahan data siswa lebih efisien
\end{abstract}

Kata kunci-Sistem Informasi, Penerimaan Siswa Baru, Siswa SMP

\begin{abstract}
Acceptance of new students is one of the processes in educational institutions such as schools that are used to select prospective students according to the criteria of the school concerned. This research was conducted at Wanasari Brebes 1 Public Middle School which still trained to receive new students manually. In the study, the researcher decided to create a Web-based Student Admission Information System at Wanasari Brebes 1 Public Middle School. The Webbased Student Admissions Information System will provide internet access for people regarding Wanasari Brebes 1 Public Middle School. The goal is to help Wanasari Brebes 1 Public Middle School create an efficient system for applying and managing student data, especially for new students. The method used in this study is data collection, system development, system requirements analysis, system design, database design, and interface design. The conclusion of this study is the Web-based Student Admissions Information System at Wanasari Brebes 1 Public Middle School will be built with PHP and MySQL, so that the processing of student data is more efficient
\end{abstract}

Keywords-Information System, Acceptance of New Students, Middle School Students

\section{PENDAHULUAN}

Internet merupakan media yang dapat membawa perubahan negatif serta positif, hal tersebut tergantung dengan bagaimana cara kita mengambil manfaat untuk menunjang pola kerja sehingga dapat menghasilkan perubahan yang lebih baik. Pada zaman sekarang internet bermanfaat dalam bidang pendidikan seperti penerimaan peserta didik baru dan ujian yang dilakukan secara daring (online) dengan media computer, tetapi masih ada beberapa sekolah 
yang masih menggunakan cara manual dalam melaksanakan program PPDB seperti halnya yang terdapat pada sekolah SMP Negeri 1 Wanasari Brebes.

Sistem PPDB secara daring di sekolah-sekolah ini harus dikembangkan sehingga diharapkan akan membuat pelaksanaan PPDB yang akan dibuat pada SMP Negeri 1 Wanasari Brebes ini menjadi lebih transparan, akuntabel, serta akomodatif. Sekolah dapat mengurangi bahkan menghilangkan kecurangan-kecurangan yang terjadi pada pelaksanaan program PPDB yang dilakukan secara manual. Dengan demikian tidak akan ada lagi pihakpihak yang merasa tidak puas maupun dirugikan. Sistem ini juga akan menjadikan proses pendataan peserta baru dengan lebih mudah dan cepat. Pelaksanaan program PPDB akan menjadi lebih efisien, baik dalam hal waktu, tempat, biaya, maupun tenaga. Dengan menggunakan sistem ini, para peserta serta orang tua peserta tidak perlu bersusah payah mendatangi sekolah guna untuk sekedar melihat pengumuman maupun informasi yang berkaitan dengan pelaksanaan program PPDB khususnya di SMP Negeri 1 Wanasari Brebes.

Kapanpun serta dimanapun mereka berada, mereka dapat mencari serta mendaftar melalui komputer maupun smartphone yang terhubung dengan internet.

Berdasarkan pemaparan yang telah dijelaskan, terdapat rumusan masalah yaitu "Bagaimana merancang Sistem Informasi Penerimaan Peserta Didik Baru Berbasis Web untuk SMP Negeri 1 Wanasari Brebes" maka dari rumusan masalah tersebut penulis tertarik untuk mengambil judul "Sistem Informasi Penerimaan Peserta Didik Baru Berbasis Web di SMP Negeri 1 Wanasari Brebes". Tujuannya Untuk memberikan informasi kepada masyarakat tentang penerimaan peserta didik baru di SMP Negeri 1 Wanasari Brebes, serta mempermudah panitia dalam proses penerimaan peserta didik baru yang dapat mempercepat proses pengolahan data peserta, penyampaian informasi dan pelaporan data peserta pada SMP Negeri 1 Wanasari Brebes.

Penelitian mengenai penerimaan peserta didik baru berbasis web pernah dilakukan di SMK Nasional Berbah, dimana menurut hasil penelitiannya sistem informasi penerimaan peserta didik baru merupakan sebuah sistem yang digunakan untuk mempermudah dalam pengelolaan pendaftaran peserta didik baru diantaranya dapat melakukan pendaftaran, pendataan dan menyeleksi calon siswa baru. Selain itu, hasil pengujian menunjukkan bahwa sistem ini memenuhi aspek functional suitability sebesar 1 (baik), aspek Usability dengan skor 85,7\% (sangat layak), aspek Security berada pada level 2 (Medium) dan aspek Performance Efficiency menghasilkan grade A dengan skor 93,17 menggunakan tool Yslow dan skor ratarata PageSpeed 88,30[1]. Penelitian mengenai penerimaan peserta didik baru juga pernah dilakukan dengan berbasis web dan sms gateway. Hasil penelitian menunjukkan tingkat kelayakan oleh ahli sistem informasi sebesar 95\% yang masuk dalam kategori layak, ahli pemrograman sebesar $78 \%$ yang dikategorikan layak, siswa sebesar 84,73\% masuk dalam kategori layak, petugas sebesar $85,64 \%$ yang dikategorikan layak, dan admin sebesar 74,74\% yang masuk dalam kategori layak. Sehingga dapat disimpulkan Sistem Informasi Penerimaan Peserta Didik Baru (PPDB) Online Berbasis Web Dan SMS Gateway Di SMA Negeri 2 Klaten termasuk dalam kategori layak sebagai sistem informasi[2]. Selain itu penerimaan peserta didik baru juga dapat dikembangkan dengan menggunakan android, Hasil yang didapatkan dalam penelitian Sistem Informasi Penerimaan Peserta Didik Baru Berbasis Andoid Menggunakan Metode Agile adalah kemudahan peserta didik baru dalam melakukan pendaftaran di SMK 17 Agustus Genteng Banyuwangi dan metode agile dapat menyesuaikan terhadap perubahan yang ada pada penerimaan peserta didik baru dengan fitur layanan home, jadwal pendaftaran, data pendaftar, formulir pendaftaran dan persyaratan pendaftaran, sehingga dapat mempermudah panitia dalam mengelola data peserta didik baru yang mendaftar dari SMP/MTs dan informasi pengumuman penerimaan peserta didik baru[3]. Dengan adanya sistem informasi berbasis website maka SMA Negeri 1 Ngemplak akan menyajikan informasi mengenai Penerimaan Peserta Didik Baru di SMA Negeri 1 Ngemplak kabupaten boyolali secara online. Sehingga sistem informasi Penerimaan peserta didik baru di SMA 1 ngemplak akan tercipta suatu sistem informasi yang dinamis, interaktif dan efektif yang di akses masyarakat luas[4] 


\section{METODE PENELITIAN}

a. Metode Pengumpulan Data

- Observasi

Observasi dilakukan dengan cara melakukan pengamatan serta terlibat langsung dalam kegiatan lapangan yang berhubungan dengan penelitian yang dijalankan. Dengan melakukan pengamatan langsung, di SMP Negeri 1 Wanasari Brebes pada bagian akademik sekolah serta pada bagian kesiswaan.

- Wawancara

Wawancara dilakukan dengan melalui pengumpulan data yaitu melakukan sesi tanya jawab secara langsung dengan pihak yang terkait untuk dapat mengetahui gambaran sistem yang ada dan telah digunakan.

b. Metode Pengembangan Sistem

Metode pengembangan sistem yang digunakan dalam pembuatan sistem informasi penerimaan peserta didik baru berbasis web di SMP Negeri 1 Wanasari Brebes yaitu dengan Model Waterfall merupakan salah satu model SDLC yang sering disebut dengan model konvensional atau classic life cycle. Model ini menggunakan pendekatan sistematis serta urut yang dimulai dari level kebutuhan sistem kemudian menuju ke tahapan analisis, desain, coding, dan testing (pengujian).

c. Analisis Kebutuhan Sistem

Dalam analisis kebutuhan sistem penelitian ini bertujuan untuk mengetahui teknologi maupun perangkat yang cocok diterapkan pada sistem ini, baik perangkat lunak maupun perangkat keras serta siapa yang akan menjalankan sistem.

- Kebutuhan Perangkat Keras

1) Seperangkat komputer atau laptop minimal core 2 duo dengan kecepatan processor $2.20 \mathrm{GHz}$.

2) Ram minimal $1 \mathrm{~GB}$.

3) Hardisk minimal 320GB.

4) Memori Graphics (VGA) minimal 256MB.

5) Monitor atau LCD.

6) Keyboard dan Mouse.

- Kebutuhan Perangkat Lunak

1) Sistem Operasi Windows 7 Ultimate.

2) Xampp, digunakan sebagai PHP dan MySQL server.

3) Sublime text, digunakan sebagai text editor coding sistem.

4) Adobe Photoshop dan Corel Draw, digunakan untuk desain tampilan sistem.

5) Web Browser seperti Google Chrome, Mozilla, UC browser dan sejenisnya.

\section{HASIL DAN PEMBAHASAN}

a. perancangan sistem

pada perancangan, penulis menggunakan diagram kontek, DFD, ERD, dan perancangan database. Dimana tujuan dari diagram kontek adalah mengetahui keadaan sistem yang akan dibangun [5]. Gambar 1 adalah diagram kontek untuk sistem yang dibuat.

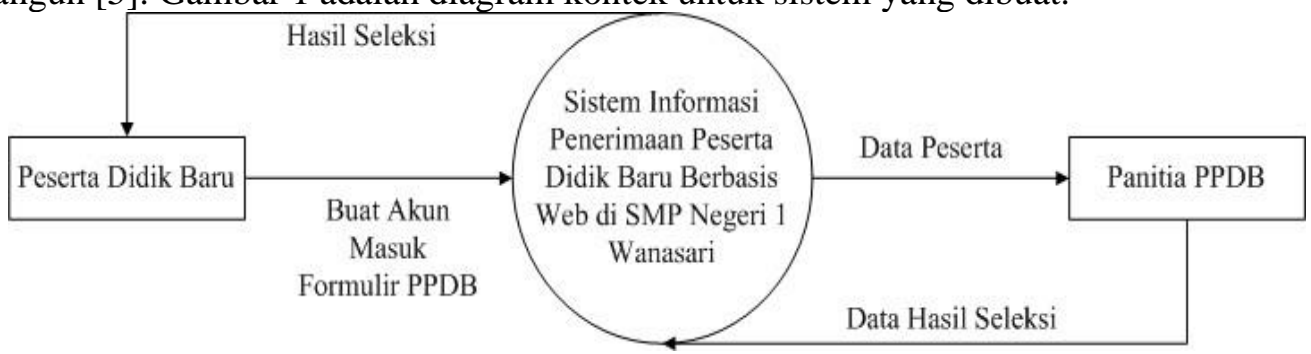

Gambar 1. Diagram kontek 
Berdasarkan Gambar 1, maka penulis akan memecahkannya menjadi data flow diagram (DFD) di Gambar 2. DFD adalah suatu model logika data atau proses yang dibuat lebih mendetail dibanding diagram konteks yang diperbolehkan, bisa dicapai dengan mengembangkan diagram. Sisa diagram asli dikembangkan ke dalam gambaran yang lebih terperinci yang melibatkan tiga sampai Sembilan proses dan menunjukkan penyimpanan data dan aliran data baru pada level yang lebih rendah[6].

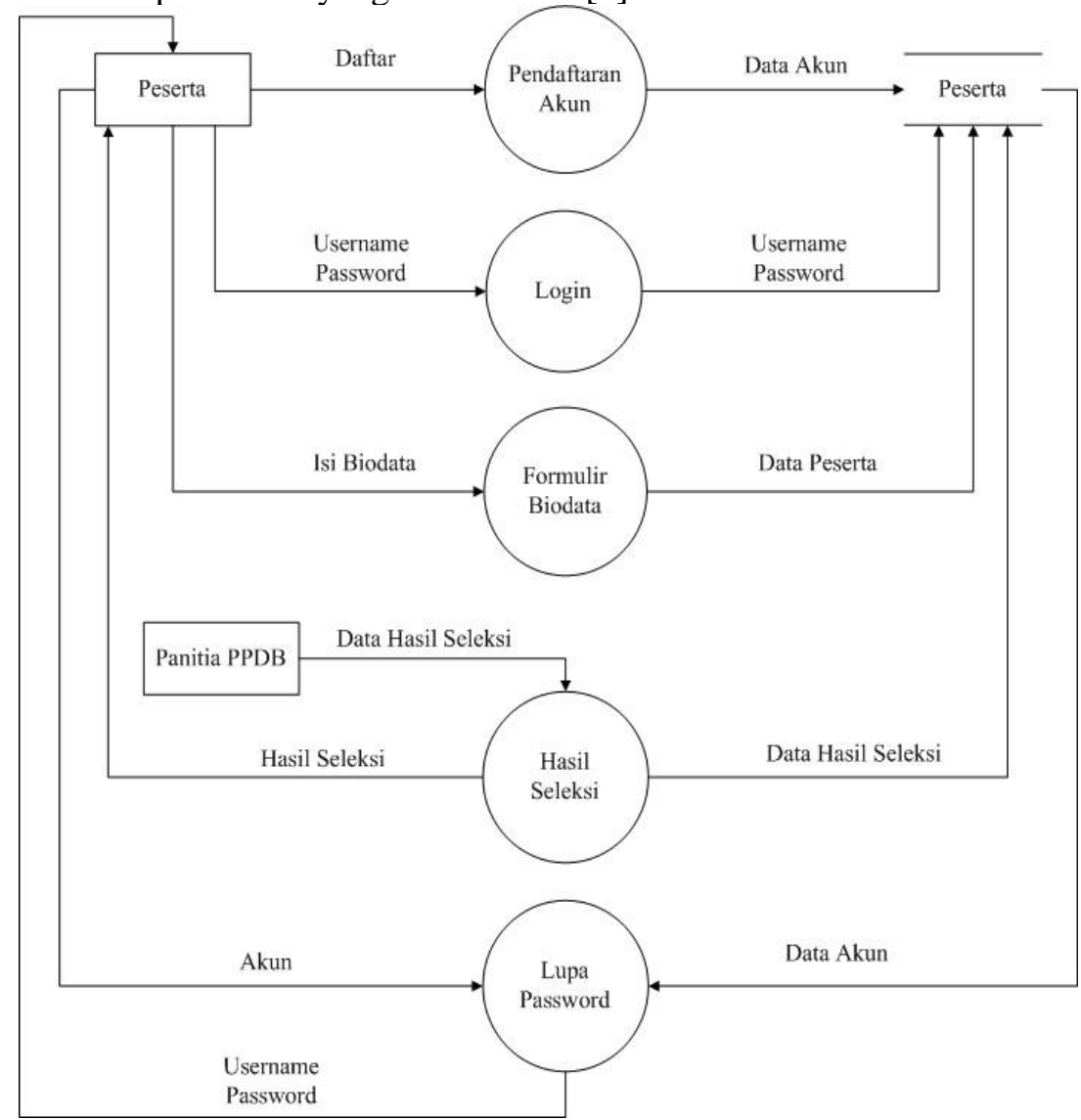

Gambar 2. DFD level 0

DFD level 0 merupakan pengembangan dari diagram konteks, DFD level 1 merupakan pengembangan dari DFD level 0. Tiap proses dari DFD dapat dikembangkan lagi menjadi lebih detail sampai proses-proses tersebut tidak dapat dikembangkan lagi[7]

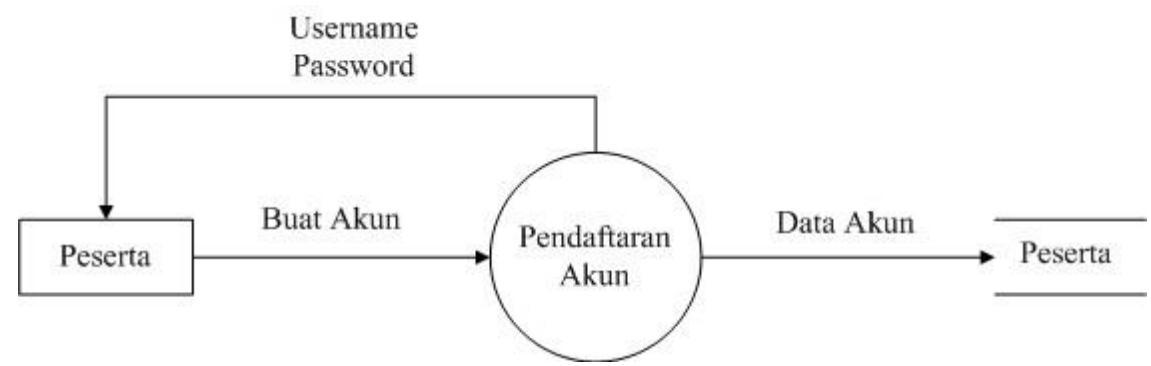

Gambar 3. DFD level 1 


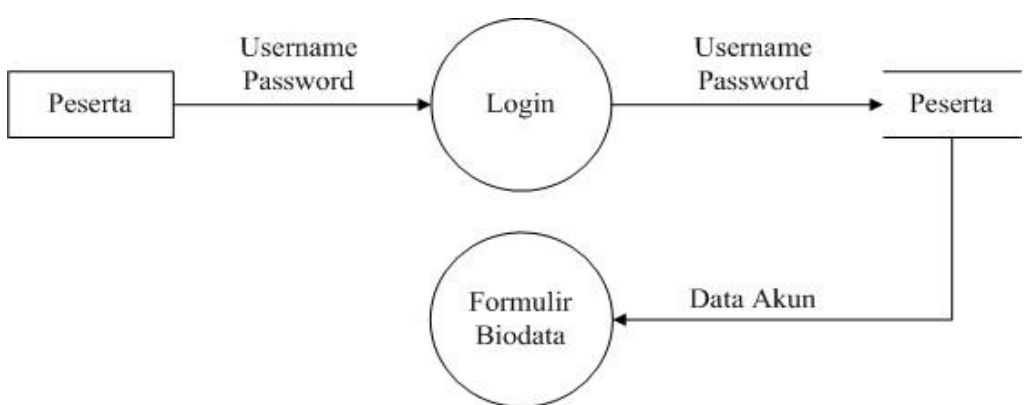

Gambar 4. DFD level 2

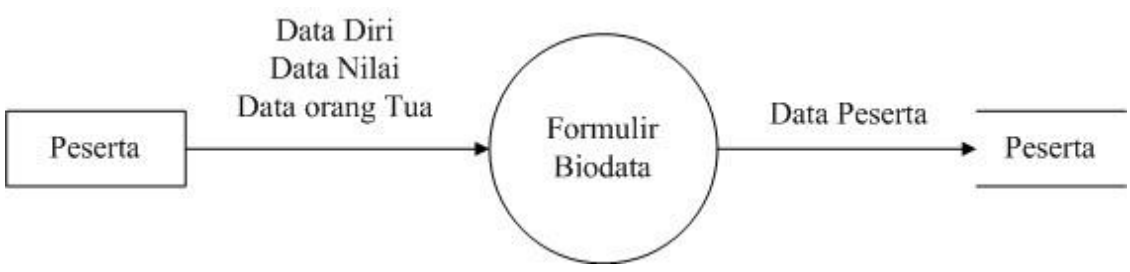

Gambar 5. DFD level 3

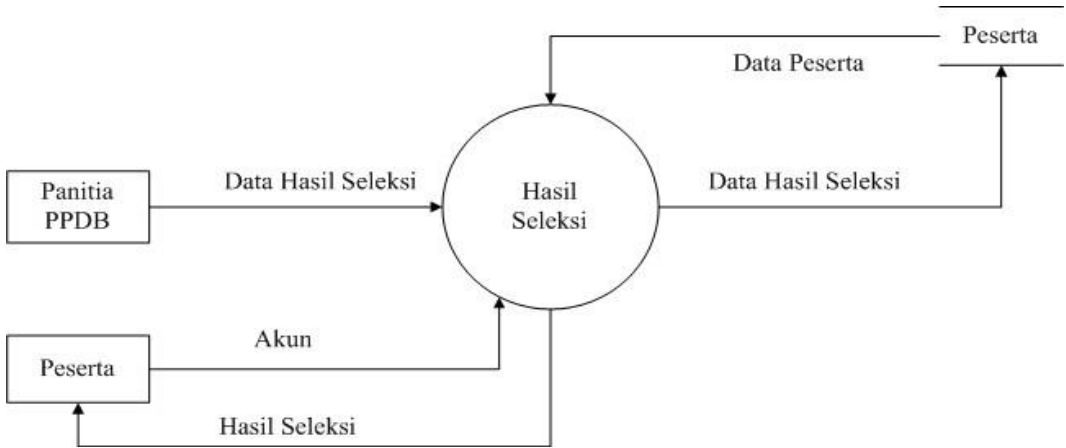

Gambar 6. DFD level 4

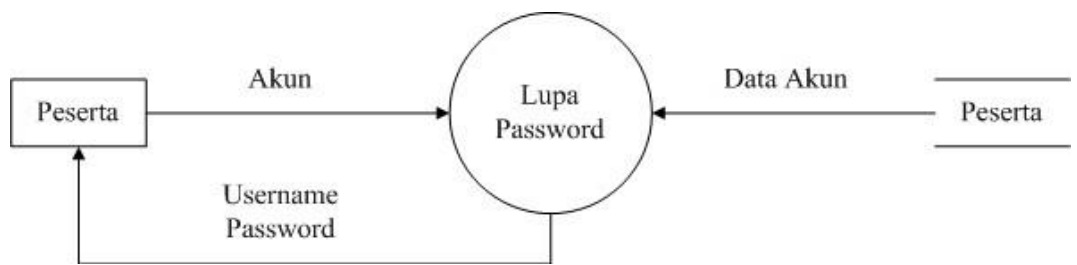

Gambar 7. DFD level 5

ERD (Entity Relationship Diagram) adalah model teknik pendekatan yang menyatakan atau menggambarkan hubungan suatu model. Didalam hubungan ini tersebut dinyatakan yang utama dari ERD adalah menunjukan objek data (Entity) dan hubungan (Relationship), yang ada pada Entity berikutnya[8]. Gambar 8 adalah ERD dari sistem yang dibuat. 


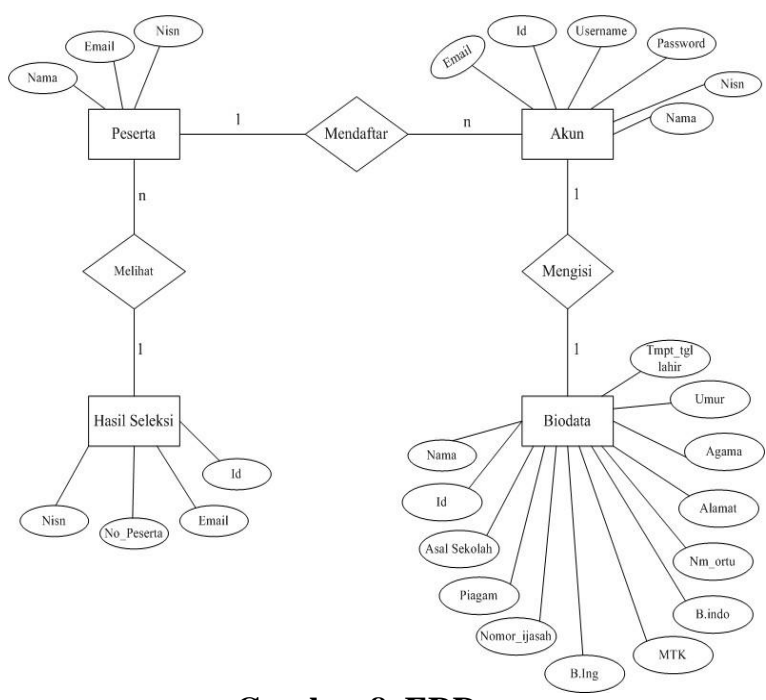

Gambar 8. ERD

Perancangan merupakan proses pemecahan masalah yang disertai dengan pemikiran yang kreatif guna mencapai hasil yang optimal. Kata perancangan atau dalam bahasa Inggris "Design" mempunyai arti "to plan and manage everything to be better", merencanakan atau mengatur segala sesuatu agar menjadi lebih baik[9].

Tabel 1. Admin

\begin{tabular}{|c|l|l|c|l|}
\hline No & \multicolumn{1}{|c|}{ Field Name } & \multicolumn{1}{c|}{ Type } & Width & \multicolumn{1}{c|}{ Keterangan } \\
\hline 1 & id & Tinyint & 2 & Id_admin \\
\hline 2 & nama & Varchar & 32 & Nama user \\
\hline 3 & username & Varchar & 32 & Nama login \\
\hline 4 & Password & Char & 32 & Password login \\
\hline 5 & Level & Enum & 2 & Jabatan user \\
\hline
\end{tabular}

Tabel 2. Pengumuman

\begin{tabular}{|c|l|l|c|l|}
\hline No & \multicolumn{1}{|c|}{ Field Name } & \multicolumn{1}{c|}{ Type } & Width & \multicolumn{1}{c|}{ Keterangan } \\
\hline 1 & id & Smallint & 4 & Id_pengumuman \\
\hline 2 & judul & Varchar & 64 & Judul pengumuman \\
\hline 3 & isi & Text & -- & Isi pengumuman \\
\hline
\end{tabular}

b. user interface sistem

pada tahapan ini peneliti akan menampilkan interface dari sistem yang dibuat meliputi menu Home, peserta, pendaftaran, informasi yang terdiri dari jadwal dan prosedur, bantuan yang terdiri dari kontak, lupa password, hasil seleksi, peserta, cetak biodata, panitia.

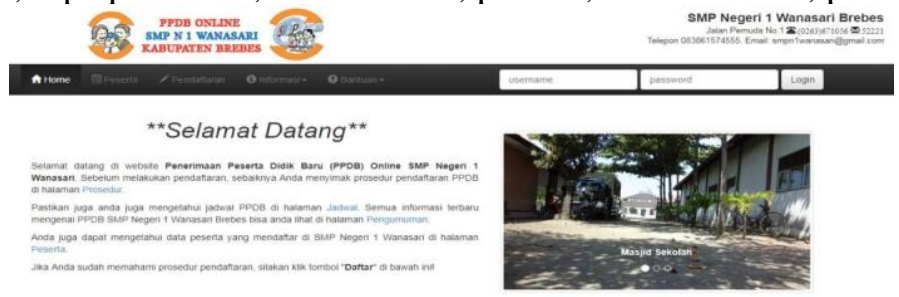

Gambar 9. Home dari sistem 


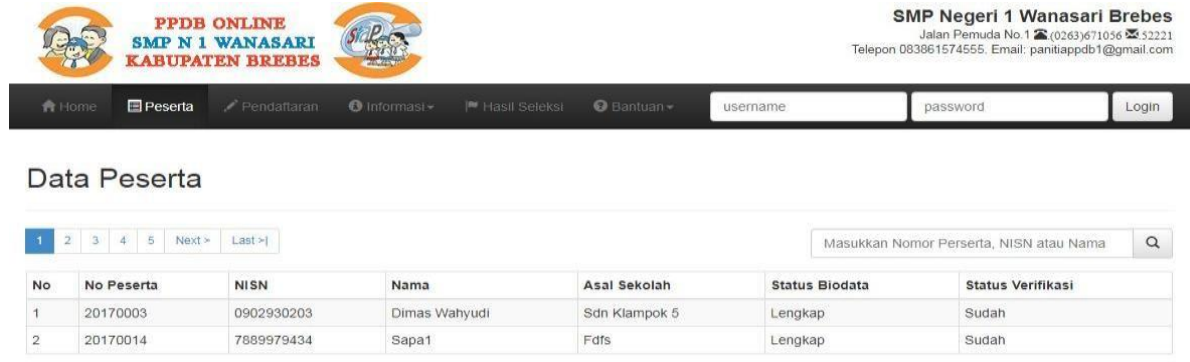

\section{Gambar 10. Halaman peserta}

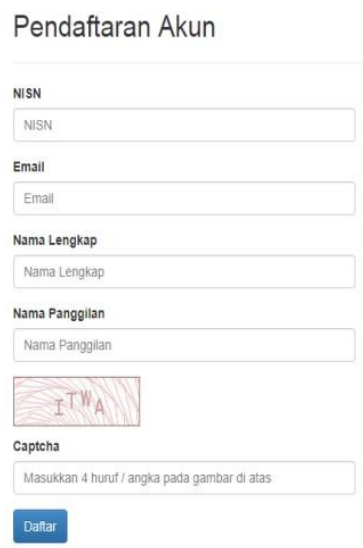

Gambar 11. Pendaftaran akun

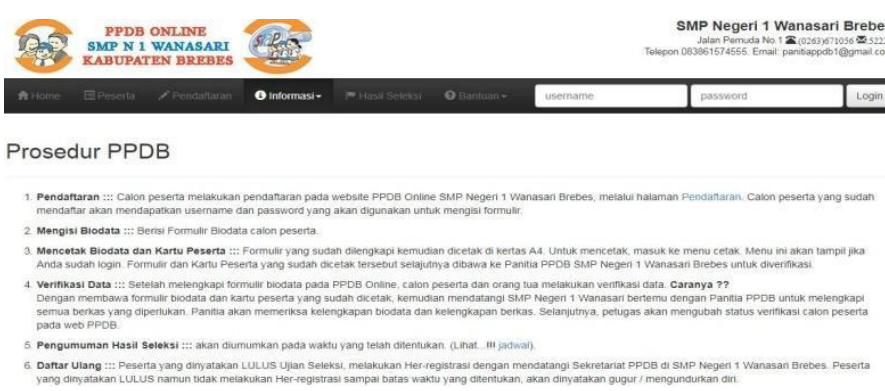

Gambar 12. Halaman prosedur

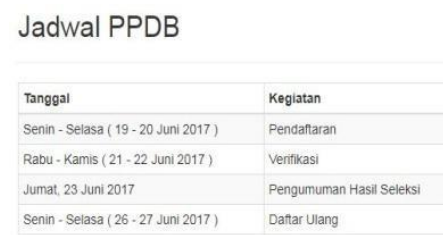

Gambar 13. Halaman jadwal

Kontak
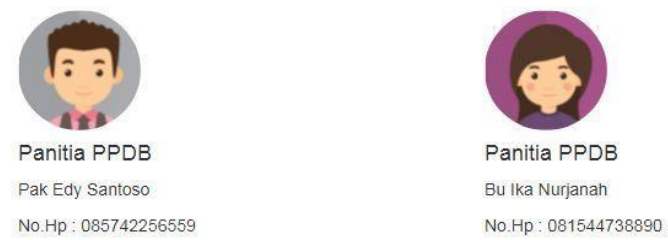

Gambar 14. Halaman kontak 


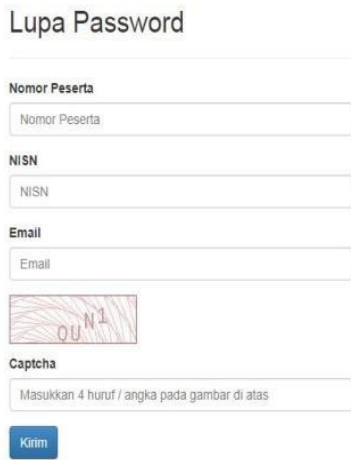

Gambar 15. Halaman lupa password

Hasil Seleksi

Nomor Peserta

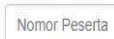

Gambar 16. Halaman hasil seleksi

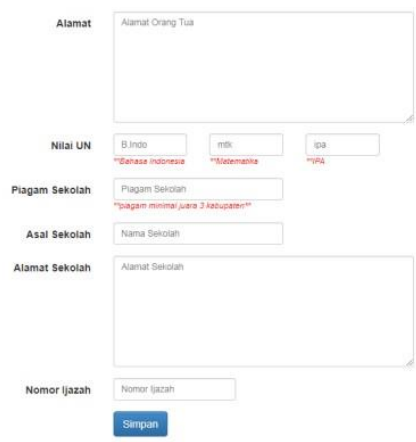

Gambar 17. Halaman biodata

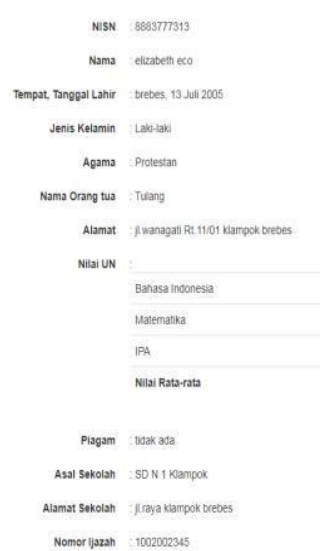




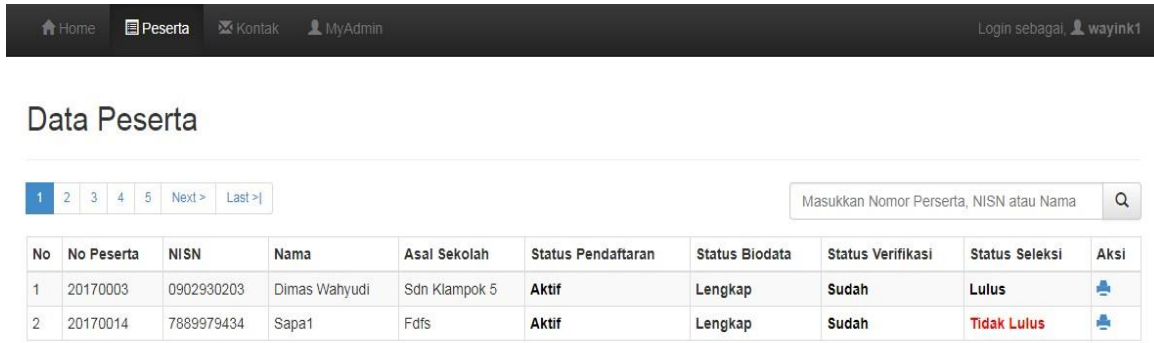

\section{Gambar 19. Halaman panitia}

c. pengujian sistem

Pengujian software sangat diperlukan untuk memastikan software/aplikasi yang sudah/sedang dibuat dapat berjalan sesuai dengan fungsionalitas yang diharapkan[10].

Tabel 3. Pengujian blackbox

\begin{tabular}{|c|l|l|l|}
\hline No & \multicolumn{1}{|c|}{ Nama Uji } & \multicolumn{1}{|c|}{ Hasil } & Kesimpulan \\
\hline 1 & Home & Tampil halaman home & Sesuai \\
\hline 2 & Halaman peserta & Tampil halaman peserta & Sesuai \\
\hline 3 & Halaman pendaftaran & $\begin{array}{l}\text { Tampil halaman pendaftaran dan } \\
\text { siswa dapat mendaftar }\end{array}$ & Sesuai \\
\hline 4 & Halaman prosedur & Tampil halaman prosedur & Sesuai \\
\hline 5 & Halaman jadwal & Tampil halaman jadwal & Sesuai \\
\hline 6 & Halaman kontak & Tampil halaman kontak & Sesuai \\
\hline 7 & Halaman lupa password & $\begin{array}{l}\text { Tampil halaman lupa password } \\
\text { dan sistem dapat mengkonformasi } \\
\text { password baru }\end{array}$ & Sesuai \\
\hline 8 & Halaman hasil seleksi & Tampil halaman hasil seleksi & Sesuai \\
\hline 9 & Halaman biodata & Tampil halaman biodata siswa & Sesuai \\
\hline 10 & Halaman cetak biodata & $\begin{array}{l}\text { Tampil halaman cetak biodata dan } \\
\text { sistem mampu mencetak dalam } \\
\text { bentuk PDF }\end{array}$ & Sesuai \\
\hline 11 & Halaman panitia & $\begin{array}{l}\text { Tampil halaman panitia dan sistem } \\
\text { mampu mengolah data panitia }\end{array}$ & Sesuai \\
\hline
\end{tabular}

\section{KESIMPULAN}

Berdasarkan hasil penelitian dan pembahasan terhadap Sistem Informasi Penerimaan Peserta Didik Baru Berbasis Web di SMP Negeri 1 Wanasari Brebes, panitia PPDB dapat mengelola pelaksanaan program PPDB dengan baik seperti pendaftaran peserta, pendataan peserta, hasil seleksi peserta dan daftar ulang peserta dengan lebih efisien, baik dalam hal waktu, tempat, biaya, tenaga maupun kecurangan yang terjadi dalam pelaksanaan program penerimaan peserta didik baru.

\section{DAFTAR PUSTAKA}

[1] Munah Kholisatul, 2018, Sistem Informasi Penerimaan Peserta Didik Baru (PPDB) Berbasis Web Menggunakan PHP dan MySQL Di SMK Nasional Berbah, Skripsi, Program Studi Pendidikan Teknik Informatika Fakultas Teknik Universitas Negri Yogyakarta. 
[2] Hariyati, Ririn., 2012, Sistem Informasi Penerimaan Peserta Didik Baru (PPDB) Online Berbasis Web dan Sms Gateway Di SMA Negri 2 Klaten, Skripsi, Program Studi Pendidikan Teknik Informatika Fakultas Teknik Universitas Negri Yogyakarta.

[3] Zaef, R.M., Herbaviana, N.C., Chusyarini, A., 2018, "Sistem Informasi Penerimaan Peserta Didik Baru Berbasis Android Menggunakan Metode Agile", Konferensi Nasional Sistem Informasi STMIK Atma Luhur Pangkalpinang, available : http://jurnal.atmaluhur.ac.id/index.php/knsi2018/article/view/363/288

[4] Prabowo, Iwan Andi., 2015, "Sistem Informasi Penerimaan Peserta Didik Baru SMA Negri I Ngemplak Kabupaten Boyolali”, Jurnal Ilmiah Sinus STMIK Sinar Nusantara Surakarta Vol 3 No 2. Available: https://www.p3m.sinus.ac.id/jurnal/index.php/ejurnal SINUS/article/view/220/pdf 49

[5] Abdullah, Dahlan., 2015, "Perancangan Sistem Informasi Pendataan Siswa SMP Islam Swasta Darul Yatama Berbasis WEB", IJNS Indonesian Journal of Network \& Security Volume $\quad 4 \quad$ Nomor $1 . \quad$ Available http://ijns.org/journal/index.php/ijns/article/view/1325/1313

[6] Rivai, Dani Ainur., Purnama, Bambang Eka., 2014, "Pembangunan Sistem Informasi Pengolahan Data Nilai Siswa Berbasis Web Pada Sekolah Menengah Kejuruan (SMK) Miftahul Huda Ngadirejo", IJNS Indonesian Journal of Network \& Security Volume 3 No 2. Available : http://ijns.org/journal/index.php/ijns/article/view/97/94

[7] Nataniel., Hatta, Heliza Rahmania., 2009, "Perancangan Sistem Informasi Terpadu Pemerintah Daerah Kabupaten Paser", Informatika Mulawarnam Jurnal Ilmiah Ilmu Komputer Volume 4 No 1 . Available : http://ejournals.unmul.ac.id/index.php/JIM/article/view/27/pdf

[8] Fridayanthie, Eka Wida., Mahdiati, Tias., 2016, "Rancang Bangun Sistem Informasi Permintaan ATK Berbasis Intranet (Studi Kasus Kejaksaan Negri Rangkasbitung)", Jurnal Khatulistiwa Informatika Volume IV No 2. Available : http://ejournal.bsi.ac.id/ejurnal/index.php/khatulistiwa/article/view/1264/1029

[9] Hutahaean, Harvei Desmon., Sinaga, Bosker., Rajagukguk, Anastasya Aritonang., 2016, "Analisa dan Perancangan Aplikasi Algoritma Apriori Untuk Korelasi Penjualan Produk (Studi Kasus Apotik Diory Farma)", Journal Of Informatic Pelita Nusantara Volume 01 No 1. Available : http://e-jurnal.pelitanusantara.ac.id/index.php/JIPN/article/view/149/70

[10] Mustaqbal, M Sidi., Firdaus, Roeri Fajri., Rahmadi, Hendra., 2015, "Pengujian Aplikasi Menggunakan Blackbox Testing Boundary Value Analysis (Studi Kasus Aplikasi Prediksi Kelulusan SNMPTN)", Jurnal Ilmiah Teknologi Informasi Terapan Volume I No 3, Available : http://jitter.widyatama.ac.id/index.php/jitter/article/view/70/50 